OPEN ACCESS

Nano Biomed Eng

ISSN 2150-5578 http://nanobe.org

\title{
A Review: Biological Synthesis Of Silver And Copper Nanoparticles
}

\author{
Ratnika Varshney ${ }^{1 *}$, Seema Bhadauria ${ }^{1}$, Mulayam S. Gaur ${ }^{2}$ \\ ${ }^{1}$ Microbiology and Nanotechnology Research Lab, R. B. S. College, Agra, India. \\ ${ }^{2}$ Department of Physics, Hindustan College of Science \& Technology, Mathura, India. \\ * Corresponding author:ratnika_bt@rediffmail.com(Ratnika Varshney)
}

Tel/fax.: +919696691824

\begin{abstract}
The antimicrobial properties of silver nanoparticles were known since ancient times and silver ions are widely used as bactericidal agent. Researchers have also recommended the use of silver and copper ions as superior disinfectants for wastewater generated from hospitals containing infectious microorganisms. A wide range of nanophasic and nanostructured particles are being fabricated globally with the aim of developing clean, nontoxic and eco-friendly technologies. Use of ambient biological resources in this area of science is rapidly gaining importance owing to its growing success and simplicity. Currently, simple prokaryotes to complex eukaryotic organisms including higher angiospermic plants are used for the fabrication of NPs. One area of untapped potential is the use of microbes to fabricate copper nanoparticles. We are working on this aspect and successfully fabricated spherical copper nanoparticles of size 4-10 nm. This article presents a review of the ambient biological systems for fabrication of these nanoparticles and development of an updated knowledge base.
\end{abstract}

Keywords: Bioreduction, Biosynthesis, Silver, Copper, Bacteria, Fungi, Algae.

Citation: Ratnika Varshney, et al. A Review: Biological Synthesis Of Silver And Copper Nanoparticles. Nano Biomed. Eng. 2012, 4(2), 99-106. DOI: $10.5101 /$ nbe.v4i2.p99-106.

\section{Introduction}

Microbial contamination of water poses a major threat to public health. With the emergence of microorganisms resistant to multiple antimicrobial agents, there is an increased demand for improved disinfection methods [1]. The antimicrobial properties of silver nanoparticles are well-established since ancient times and silver ions are widely used as bactericide in catheters, burn wounds and dental work [2, 3] and several mechanisms for their bactericidal effects have been proposed. Although only a few studies have reported the antibacterial properties of copper nanoparticles, they show copper nanoparticles have a significant promise as bactericidal agent [4] Yoon et al. reported the antibacterial effects of silver and copper nanoparticles using single representative strains of E. coli and Bacillus subtilis, where the copper nanoparticles demonstrated superior antibacterial activity compared to the silver nanoparticles [5]. Researchers have also recommended the use of silver and copper ions as superior disinfectants for wastewater generated from hospitals containing infectious microorganisms $[6,7]$. However, residual copper and silver ions in the treated water may adversely affect human health [8].
The emergence of nanoscience and nanotechnology in the last decade presents opportunities for exploring the bactericidal effect of metal nanoparticles. The bactericidal effect of metal nanoparticles has been attributed to their small size and high surface to volume ratio, which allows them to interact closely with microbial membranes and is not merely due to the release of metal ions in solution [9]. Metal nanoparticles with bactericidal activity can be immobilized and coated on to surfaces, which may find application in various fields, i.e., medical instruments and devices, water treatment and food processing. Metal nanoparticles may be combined with polymers to form composites for better utilization of their antimicrobial activity. Metal nanoparticles are also finding application in various other fields, i.e., catalysis and sensors [10, 11]. Nature has elegant and ingenious ways of creating the most efficient miniaturized functional materials.

In attempts to create miniaturized structures, significant achievements have been achieved and structures of micron and nano-dimensions can now be routinely fabricated though the complexity manifested by the 
nature is yet a distant goal. In the current context, importance is being given to the fabrication of a wide range of nanomaterials for developing environmentally benign technologies in material synthesis [12]. Despite of their minute structure, they trigger the chemical activity due to their distinctive crystallographic nature that increases surface area, hence the scope of reactivity [13, 14]. In recent times, synthesis of inorganic nanoparticles has been demonstrated by many physical and chemical means. But the importance of biological synthesis is being emphasized globally at present because chemical methods are capital intensive, toxic, non eco-friendly and have low productivity [15]. Utilizing potential biological systems from higher angiospermic plants or microbes, biosynthesis of NPs is currently under wide exploration [16, 17]. These ambient biological systems provide excellent examples of nanophasic materials with highly optimized characteristics resulting from evolution over a long scale of time [18] and the synthesis of inorganic materials may occur either extracellularly or intracellularly [19]. Exposure to varying temperature, $\mathrm{pH}$ and substrate concentration influences, directly or indirectly, the rate of intracellular NPs fabrication [20]. It is important to understand the biosynthetic mechanism involved in the fabrication of metal nanomaterials mediated by a biological system in order to gain better control of the process and products. So far, little is known about the interaction between biomolecules and NPs, though several analyses have been made. It is reported that bioreduction of metal ions and stabilization of $\mathrm{Au}$ or Ag-NPs is primarily caused by various terpenoids or alkaloids present in the Geranium, extract itself [21].

It is a need of today's nanotechnology to develop reliable, non-toxic, clean and eco-friendly experimental protocols for the synthesis of silver and copper NPs over a range of chemical composition, size and synchronized monodispersity, which is possible through ambient biological resources. In the last few years a lot of reviews have been published [12, 22, 23], it is necessary further to elaborate this technology in a consolidated way with an approach that provides an overview of the current trend of research on the biosynthesis of $\mathrm{Ag}$ and $\mathrm{Cu}-\mathrm{NPs}$ for their further applications. The present review highlights the current knowledge regarding the potential organisms for biosynthesis of these NPs and presents a database that future researchers can build upon.

\subsection{Fabrication of Nanoparticles Using Bacteria}

The most important challenge in nanotechnology today is to cost effectively tailor the optical, electric and electronic property of NPs by controlling the configuration as well as monodispersity. This goal could be achieved using bacterial organisms in an organized manner [20]. In the last few years, fabrication of AgNPs has increased extensively owing to its immense applications[9]. Pseudomonas stutzeri AG259 has been reported to fabricate Ag particles[24], which are accumulated within the periplasmic space of bacterial

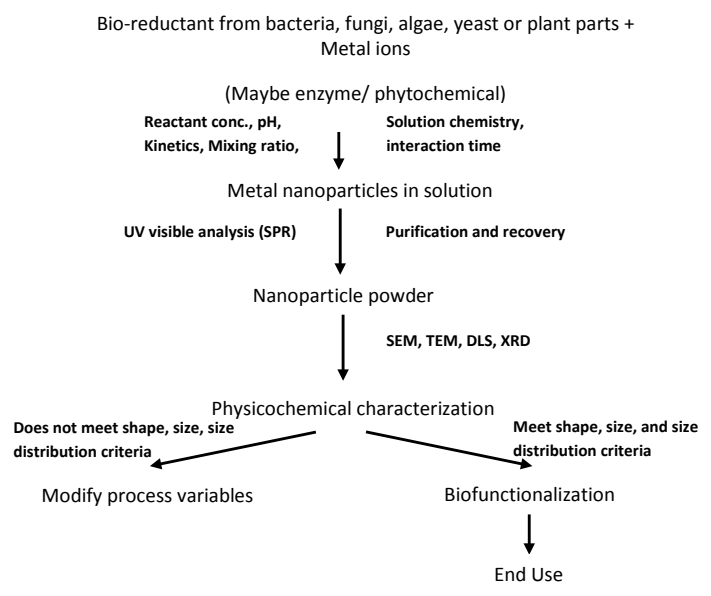

Fig. 1 Generalized Flow Chart for Biosynthesis of Nanoparticles

cell of $200 \mathrm{~nm}$. Lactobacillus, a common bacterial strain present in the buttermilk, synthesizes both $\mathrm{Au}$ and $\mathrm{Ag}$ NPs under standard conditions[25]. Rapid synthesis of metallic NPs of Ag using the reduction of aqueous $\mathrm{Ag}^{+}$has been achieved in the cultural supernatants of Klebsiella pneumonia, Escherichia coli and Enterobacter cloacae [26]. Recently detailed studies confirmed that synthesis of Ag can be triggered through the liquid mixing process developed in the visible light spectrum by Klebsiella pneumonia [27]. Extracellular biosynthesis of $40 \mathrm{~nm} \mathrm{Ag} \mathrm{NPs} \mathrm{by} \mathrm{the} \mathrm{culture} \mathrm{supernatant} \mathrm{of} \mathrm{Bacillus}$ licheniformis has been customized as an easy way to work out the process [28]. Varshney et al. have reported a rapid biological synthesis technique for the synthesis of spherical $\mathrm{Cu}$ nanoparticles of in the size range of 8-15 nm using non-pathogenic Pseudomonas stutzeri [29] (Fig. 2).

Recently, an innovative approach has been used for the synthesis of copper nanoparticles where Pseudomonas stutzeri bacterial strain was used for copper nanoparticles synthesis from electroplating waste water. The bacterial strain was isolated from soil and found that it produced 50-150 nm sized cubical copper nanoparticles [30]. Prakash et al. reported extracellular synthesis of silver nanoparticles by bacteria Bacillus cereus collected from the riverine belt of Gangetic Plain of India31. Synthesized nanoparticles were spherical in shape, and in the range of 10-30 nm in size (Fig. 3). Antibacterial effect of the synthesized Ag-NPs was tested with a gram negative and gram positive bacteria E. Coli and Streptococcus in varying strength of nanoparticles and observed that the lowest concentration up to $50 \mathrm{ppm}$ was sufficient to inhibit bacterial growth.

\subsection{Fabrication of Nanoparticles Using Yeast}

Among the simple eukaryotic organisms, yeasts are explored mostly for the fabrication of Cd-NPs and also known as 'Semiconductor Crystals' or 'Quantum Semiconductor Crystals' [32]. Ag-NPs have been fabricated extracellularly using an Ag tolerant yeast strain MKY3 [15]. They have demonstrated that MKY3, a silver-tolerant yeast species, when challenged with 
soluble silver in the log phase of growth, majority of silver precipitate extracellularly as elemental nanoparticles. They used differential thawing methods for the sample, for separation of the metallic nanoparticles from the medium. Studies are still being carried on to search further for diverse groups of beneficial yeasts.

\subsection{Fabrication of Nanoparticles Using Algae}

An alga is a diverse group in plant kingdom that is being explored for application in nanotechnology. Besides the production of NPs, algae are also being explored for determining its nutritional value, efficacy in bio-diesel improvement as well as its vast potential for therapeutic application. Govindaraju et al. reported extracellular synthesis of silver nanoparticles by a brown seaweed, Sargassum wightii [33]. Their recorded antibacterial effect against bacteria isolated from the infected silkworm, was found more potent when compared to the chemically synthesized silver nanoparticles and it is expected to be biocompatible. Mohseniazar et al. demonstrated that Nannochloropsis oculata and Chlorella vulgaris have the potential of nanosilver production in a culture medium containing $1 \mathrm{mM}$ of $\mathrm{AgNO}_{3}$ within $24 \mathrm{~h}$. The size range of particles was approximately less than $15 \mathrm{~nm}$ [34].

\subsection{Fabrication of Nanoparticles Using Fungi}

The fungal mediated green chemistry approach towards the fabrication of NPs has many advantages. This includes easy and simple scale up method, economic viability, easy downstream processing and biomass handling, and recovery of large surface area with optimum growth of mycelia. It has been observed that most of the fungal genera are coupled with the synthesis of Ag-NPs either intracellularly or extracellularly showing the onset of deep brown coloration [35]. Aqueous Ag ions exposed to Fusarium oxysporum leads to the fabrication of extremely stable Ag hydrosol. The particles are stabilized in solution by the proteins excreted through the fungus [36]. Extracellular biosynthesis of Ag-NPs in the 5-25 nm range using Aspergillus fumigatus is found to be quite fast and manifested the production of dense fungal biomass [37]. White rot fungus, scientifically known as Phaenerochaete chrysosporium has also been used for biomimetics of AgNPs [38]. When Aspergillus flavus has been challenged with $\mathrm{AgNO}_{3}$ solution it accumulated Ag-NPs [39] on the surface of its cell wall. The TEM micrographs of dislodged NPs in aqueous solution confirmed the fabrication of convincingly monodispersed NPs of size $8.92 \pm 1.61 \mathrm{~nm}$. FTIR confirmed the existence of proteins adjoining the Ag-NPs with a distinctive emission peak at $553 \mathrm{~nm}$ excited at $420 \mathrm{~nm}$ in photoluminescence spectrum [40]. Phytochelatin and NADPH dependent nitrate reductases for in-vitro production of Ag-NPs have been isolated from Fusarium oxysporum and been elucidated [17]. Fusarium acuminatum has been studied intensely for the formation of Ag-NPs [41]. Fusarium semitectum fabricated 10-60 nm spherical NPs and the colloidal suspensions are stable for several weeks but after that stability. Possible medicinal applications of these AgNPs are envisaged [42]. Extracellular biosynthesis of AgNPs by Fusarium solani (USM-3799), a phytopathogen, has produced nanoparticles with an average diameter of $16.23 \mathrm{~nm}$. FTIR analyses provide evidence for the presence of proteins as a capping agent that enhanced the stability of synthesized Ag-NPs [43]. Further, it has been reported that functional groups, e.g. $\equiv \mathrm{C}-\mathrm{O}-\mathrm{C} \equiv$, $=\mathrm{C}=\mathrm{O}$, $\equiv \mathrm{C}-\mathrm{O}-\mathrm{R}$ and $=\mathrm{C}=\mathrm{C}=$ are being derived from heterocyclic compounds like proteins that are present in the fungal extract and act as capping ligands of NPs [44]. The genus Penicillium seems to have extremely good candidates for the fabrication of Ag-NPs. Production proceeds via extracellular mechanism with high negative zeta potential and stable at $\mathrm{pH}$ above 8.0 because of electrostatic repulsion [45]. Penicillium fellutanum, isolated from coastal mangrove sediment, is found to be highly efficient in synthesis of Ag-NPs. Production is optimized at $0.35 \% \mathrm{NaCl}, \mathrm{pH} 6.0$, incubated at $5{ }^{\circ} \mathrm{C}$ and treated with $\mathrm{AgNO}_{3}(1 \mathrm{mM})$ for $24 \mathrm{~h}$. A protein band with a molecular weight of $70 \mathrm{KDa}$ is detected when analyzed by PAGE [46]. As Penicillium is a very common biomass waste from pharmaceutical industry that possesses a potential to fabricate particles, it would enhance the opportunity for cost-effective preparation of various Ag based nanostructures. Controlling the scale-up process for biosynthesis of Ag-NPs with fungal proteins of Coriolus versicolor has been carried out [44]. Fungal biomass accumulated Ag-NPs in $72 \mathrm{~h}$, which is reduced to $1 \mathrm{~h}$ in customized reaction conditions. FTIR studies revealed that amino groups bound to particles account for the stability of NPs and established the existence of protein as the stabilizing and capping agent. Extracellular synthesis took place whereby other than the fungal proteins, glucose is found to be responsible for the reduction. While in fungal mycelium, intracellular development of Ag-NPs could be modified to give both intracellular and extracellular Ag-NPs under alkaline conditions, wherein the surface $\mathrm{S}-\mathrm{H}$ groups of the fungus play a major role. Extracellular synthesis of Ag-NPs from Phoma glomerata (MTCC2210) has been traced and its efficacy against Escherichia coli, Staphylococcus aureus and Pseudomonas aeruginosa has been evaluated [47]. Experimental evidence suggests that the extracellular production of NPs is stabilized by proteins as well as reducing agents secreted by the fungus itself. NPs have been found to be coupled with at least four high molecular weight proteins released from the biomass of fungus. FTIR indicates the native forms of these proteins [48]. Reduction of metal ions and surface binding of proteins to the NPs has been elucidated little far [17]. Studies further indicate that genera Fusarium, Aspergillus and Penicillium have large potential for the fabrication of different metal NPs. Recently Ag-NPs synthesis and its antimicrobial activity against gram positive and negative bacteria has been reported by Pleurotus sajor caju fungi [49]. We have also reported a novel fungi Hormoconis resinae for the synthesis of silver nanoparticles within the range of 20-80 nm [50]. 

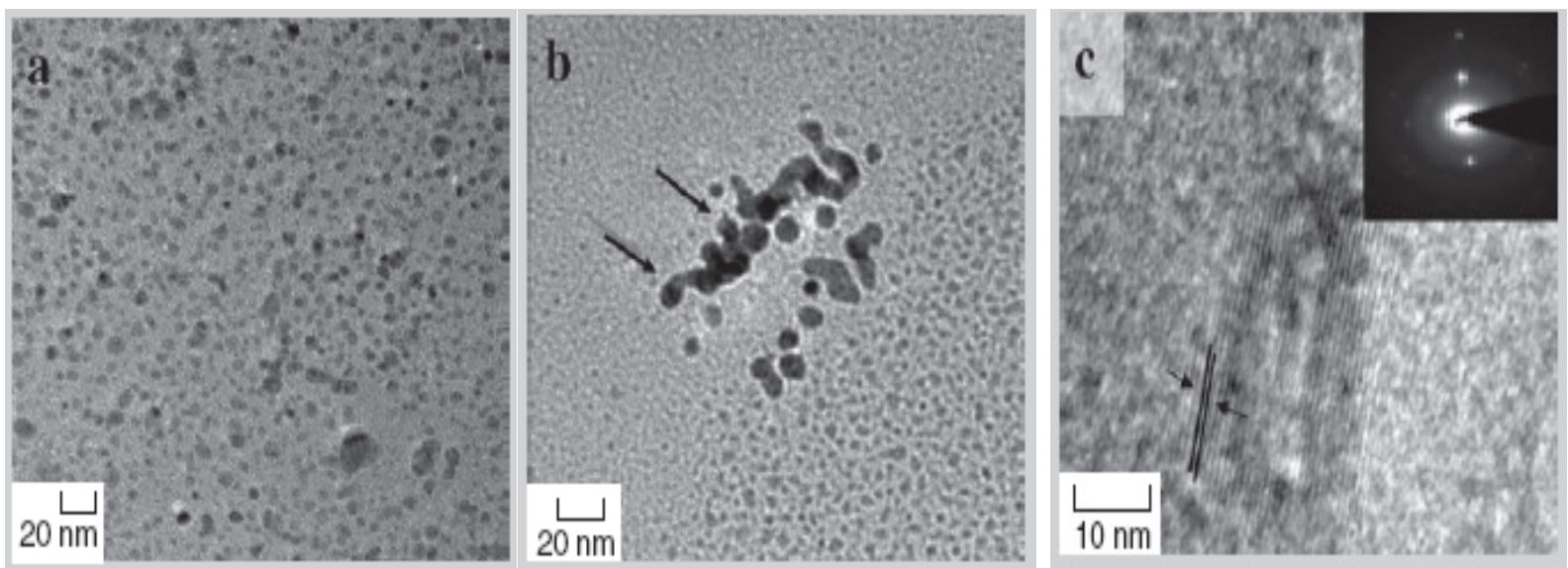

Fig. 2 HRTEM images of $\mathrm{Cu}$ nanoparticles formed by bacteria Pseudomonas stutzeri shows: (a) spherical Cu nanoparticles; (b) a thin bacterial layer around nanoparticles which acts as capping agent; (c) close-up view of nanoparticles showing lattice fringes; inset shows selected electron diffraction pattern. [Adapted from Ref. 29]
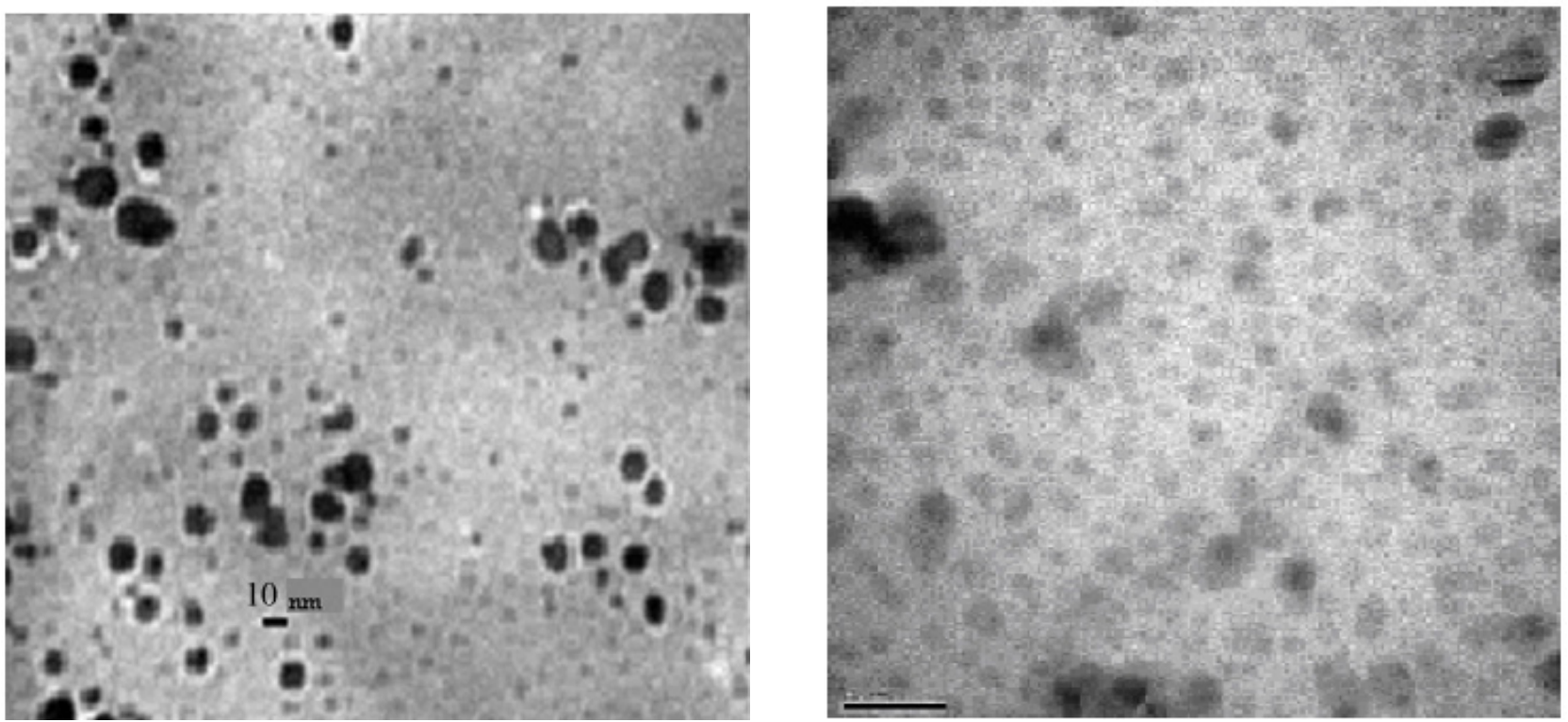

Fig. 3 TEM photographs of AgNPs from Bacillus cereus at different magnifications. [Adapted from Ref. 31]
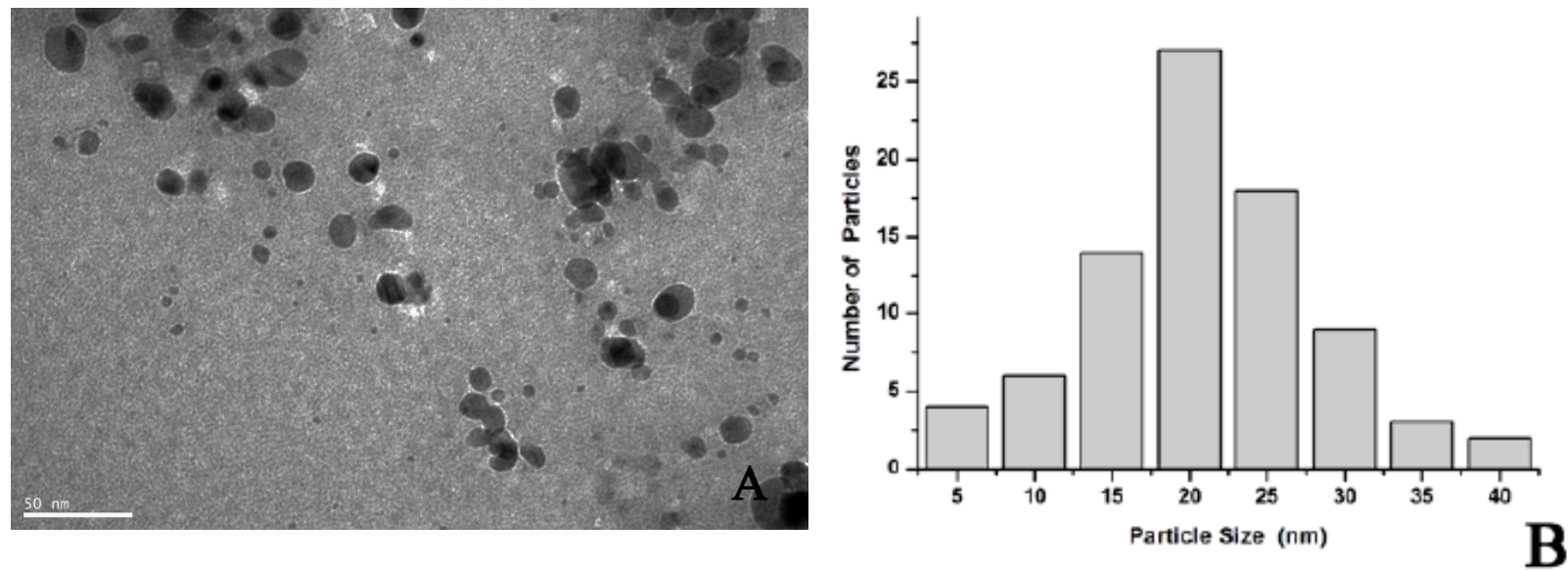

Fig. 4 (A) Representative images of AgNPs synthesized by the reduction of $\mathrm{AgNO}_{3}$ solution with the dialyzed cell filtrate of Aspergillus terreus and NADH; (B) Size distribution of the AgNPs from TEM analysis. [Adapted from Ref. 51] 


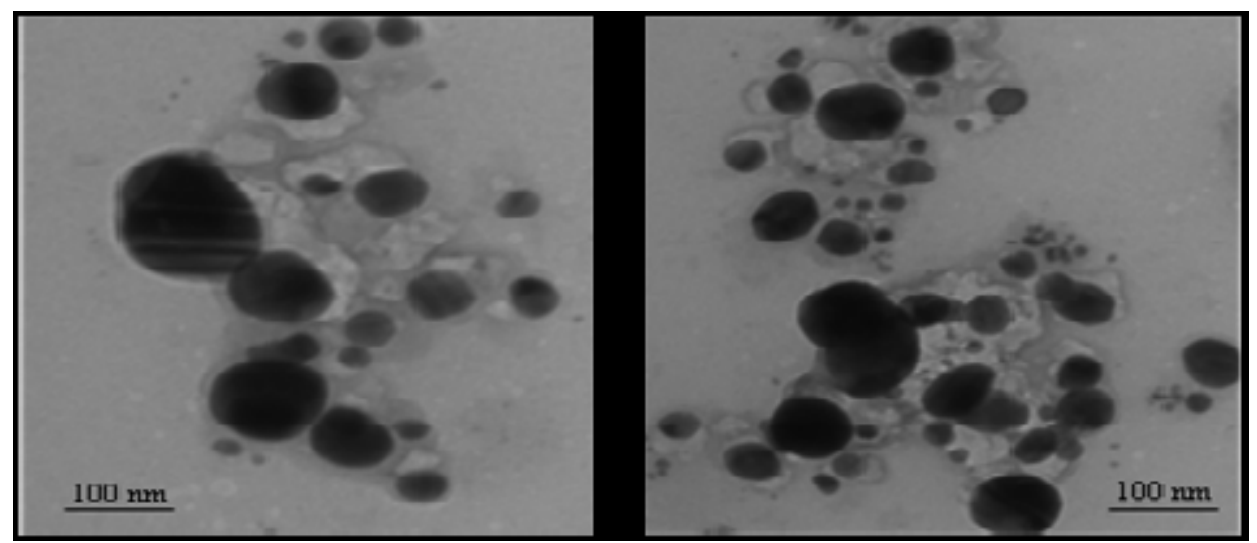

Fig. 5 Representative TEM images illustrating the formation of silver nanoparticles biologically synthesized by reduction of $\mathrm{Ag}^{+}$ions using leaf broth of Zingiber officinale. [Adapted from Ref. 73]

Very recently Li et al. demonstrated a method for AgNPs synthesis by reduction of aqueous $\mathrm{Ag}^{+}$with the culture supernatants of Aspergillus terreus at room temperature. The synthesized Ag-NPs were polydispersed spherical particles ranging in size from 1 to $20 \mathrm{~nm}$ and stabilized in the solution (Fig. 4). Reduced NADH was found to be an important reducing agent for the biosynthesis, and the formation of Ag-NPs might be an enzyme-mediated extracellular reaction process. Their antimicrobial potential was systematically evaluated and found that they could efficiently inhibit various pathogenic organisms, including bacteria and fungi [51].

\subsection{Fabrication of Nanoparticles Using Higher Angiospermic Plants}

Several microorganisms such as bacteria, fungi and yeasts have come up as nanofactories synthesizing metal NPs of Ag. However, use of plants for the fabrication of NPs has drawn attention of workers because of its rapid, economical, eco-friendly protocol and it provides a single step technique for the biosynthesis process [52]. In the extract of Geranium sp. fabrication of Ag-NPs as well as Au-NPs has been reported [53]. The leaf broth of Azadirachta indica extracellularly fabricates pure metallic $\mathrm{Ag}$ - and Au- NPs and bimetallic Au/Ag NPs. Competitive reduction of $\mathrm{Au}^{3+}$ and $\mathrm{Ag}^{+}$ions present simultaneously in solution during exposure to plant leaf extract generates bimetallic Au core and Ag shell NPs. TEM revealed Ag particles have been adsorbed on Au-NPs and constructed the former structure. Flavonone and terpenoid components of leaf broth are being predicted to stabilize the formation of NPs in contrast to high molecular weight proteins of fungal biomass [54]. The fruit extract of Emblica officinalis enhances the extracellular synthesis of highly stable Ag and Au-NPs [55]. Utilizing leaf extract of Aloe vera as a reducing agent, fabrication of $\mathrm{Au}$ nano triangles and Ag-NPs in single triangular form has been achieved [56]. Cinnamomum camphora has also been revealed to fabricate Au and Ag-NPs [52]. AgNPs have also gained significance due to their broadspectrum activity against bacterial infections. The roots of Medicago sativa accumulate Ag ions inside the plant tissue from the enriched medium and undergo nucleation and fabricate Ag-NPs [57]. Using Pelargonium graueoleus leaf extract, $\mathrm{Ag}^{+}$is reduced to $\mathrm{Ag}-\mathrm{NPs}$ that are crystalline as well as highly stabilized [58]. Bioreduction activity of leaf extracts of Helianthus annus, Basella alba, and Saccharum officinarum resulted in the fabrication of Ag-NPs in which Helianthus annus is found to exhibit strong potential for quick reduction of $\mathrm{Ag}^{+}$[59]. The polyol components and the water soluble heterocyclic components were mainly responsible for reduction of $\mathrm{Ag}^{+}$ as well as stabilization of NPs. Information regarding the activity of reductases in NP fabrication were well illustrated by Kumar et al [17]. No correlation is observed between the color development and increase in abundance exhibited by the synthesized nano metal. Differences in morphology of nanoparticles synthesized, is one possible reason for variation in optical properties [60].

Further studies reflect that several parameters together determine the NP synthesis including plant source, the organic compounds in the crude leaf extract, the concentration of $\mathrm{AgNO}_{3}$, the temperature and the pigments of the corresponding leaf extract [59]. Recently, fabrication of Ag-NPs using the callus extract of Carica papaya has been reported [61]. Brown coloration of the MS medium and analyses of FTIR confirmed the presence of proteins and other ligands that are mandatory for the synthesis and stabilization of derived spherical NPs. The use of latex of Jatropha curcas as reducing as well as capping agent in the fabrication of Ag-NPs has recently been reported [62]. Jha et al. reported the synthesis of AgNPs by Eclipta leaf fabricating 2-6 nm size particles [63]. Biosynthesis of Ag-NPs using Glycine max (soybean) leaf extract and its different varieties has been reported by Vivekanandan et al. and yield organic free particles64. Very recently several researchers exploited plant extracts for the synthesis of silver nanoparticles using Coriandrum sativum leaf extract [65]; leaf and seed extract of Syzygium cumini [66]; Cycas leaf [67], Argimone Mexicana leaf extract [68]; onion extract [69]. Varshney et al. reported a novel biological method for the synthesis of rod and cubes shaped silver nanoparticles by exploiting sundried Stevia rebaudiana leaves at ambient conditions 
and synthesized silver nanoparticles ranging from 80-200 $\mathrm{nm}$ diameter and 400-800 $\mathrm{nm}$ height [70]. Govindaraju et al. reported the biological synthesis of silver nanoparticles using Solanum torvum and its antimicrobial activity. They obtained silver nanoparticles of average size 14 $\mathrm{nm}$ and antimicrobial activity of $S$. torvum mediated silver nanoparticles was performed against pathogenic bacteria and fungi of silkworm Bombyx mori[71]. With the aim of developing new methods of producing metallic nanoparticles from materials safe for the environment, Guajardo-Pacheco et al. reported a method of producing metallic nanoparticles of copper by using soybeans extract as a chelating agent [72].

Recently Singh et al. reported biosynthesis of gold and silver nanoparticles using leaf extract of ginger (Zingiber officinale). Ag-NPs produced were spherical and with dimensions ranging from 10.1 to $65.91 \mathrm{~nm}$ with an average size of $30.31 \mathrm{~nm}$ (Fig. 5) [73].

Lee et al. reported biologically synthesized copper nanoparticles using plant leaf extract Mangolia as reducing agent. On treatment of aqueous solutions of $\mathrm{CuSO}_{4} \cdot 5 \mathrm{H}_{2} \mathrm{O}$ with leaf extract, stable copper nanoparticles were formed ranged in size from 40-100 nm. Their antibacterial properties were tested by counting viable Escherichia coli cells after $24 \mathrm{~h}$ growth and showed higher antibacterial activity compared with untreated samples [74].

\subsection{Fabrication of Nanoparticles Using Weeds}

Among the above bio-based protocols, Parashar et al. exploited the synthesis method of silver nanoparticles from weed Parthenium leaf extract [75]. Recently the bioreduction property of three aquatic weed leaves extracts such as Ipomoea aquatica (Convolvulaceae), Enhydra fluctuans (Asteraceae) and Ludwigia adscendens (Onagraceae) in the synthesis of silver nanoparticles has been investigated by Roy et al [76].

\section{Conclusion}

This paper has reviewed recent knowledge and built a data base of bioreductive approaches to Ag-NPs and $\mathrm{Cu}-$ NPs using different biological systems. There are several reports of physical and chemical synthesis of copper and copper based nanomaterials. But no reports are available on the biological synthesis of copper nanomaterials with size and shape control. It is, therefore, important to develop synthetic strategies which are simple, costeffective, environment friendly, easily scalable and at the same time with parameters to control size and shape of the materials. The exact mechanism for the fabrication of NPs in biological resources is still being investigated and several possible ways have been proposed [21, 52[. Microorganisms where proteins [44] and angiosperms where carboxylic groups, amino groups, proteins and carbohydrates [52] are present in the source extract have been proposed to play a key role in the biosorption and bioreduction process for the fabrication of NPs.

\section{References}

1. Kolar M, Urbanek K, Latal T Antibiotic selective pressure and development of bacterial resistance. Int. J. Antimicrob. Ag. 2001;17: 357-63.http://dx.doi.org/10.1016/S0924-8579(01)00317-X

2. Kim JS, Kuk E, Yu KN, Kim JH, Park SJ, Lee HJ, Kim SH, Park YK, Park YH, Hwang CY, Kim YK, Lee YS, Jeong DH, Cho MH Antimicrobial effects of silver nanoparticles. Nanomedicine, 2007; 3(1): 95-101.http://dx.doi.org/10.1016/j.nano.2006.12.001

3. Jain P, Pradeep T Potential of silver nanoparticle-coated polyurethane foam as an antibacterial water filter. Biotechnol. Bioeng. 2005; 90: 59-63.http://dx.doi.org/10.1002/bit.20368

4. Cioffi N, Torsi L, Ditaranto N, Tantillo G, Ghibelli L, Sabbatini L, Bleve-Zacheo T, D’Alessio M, Zambonin PG, Traversa E Copper nanoparticle/polymer composites with antifungal and bacteriostatic properties. Chem. Mater. 2005; 17:5255-62.http://dx.doi. org/10.1021/cm0505244

5. Yoon K, Byeon JH, Park J, Hwang J Susceptibility constants of E. coli and Bacillus subtilis to $\mathrm{Ag}$ and $\mathrm{Cu}$ nanoparticles. Sci. Total Environ.2007; 373:572-5.http://dx.doi.org/10.1016/ j.scitotenv.2006.11.007

6. Lin YE, Vidic RD, Stout JE, Yu VL Individual and combined effects of copper and silver ions on inactivation of Legionella pneumophila. Water Res.1996; 30:1905-13.http://dx.doi.org/10.1016/00431354(96)00077-2

7. Lin YE, Vidic RD, Stout JE, Mc Cartney CA, Yu VL Inactivation of Mycobacterium avium by copper and silver ions. Water Res. 1998; 32:1997-2000.http://dx.doi.org/10.1016/S0043-1354(97)00460-0

8. Blanc DS, Carrara P, Zanetti G, Francioli P Water disinfection with ozone, copper and silver ions, and temperature increase to control Legionella: seven years of experience in a university teaching hospital. J. Hosp. Infect.2005; 60:69-72.http://dx.doi. org/10.1016/j.jhin.2004.10.016

9. Morones JR, Elechiguerra JL, Camacho A, Holt K, Kouri JB, Ramirez JT, Yacaman MJ The bactericidal effect of silver nanoparticles. Nanotechnology, 2005; 16:,2346-53.http://dx.doi. org/10.1088/0957-4484/16/10/059

10. Vaseashta A, Dimova-Malinovska D Nanostructured and nanoscale devices, sensors and detectors. Sci. Technol. Adv. Mater. 2005; 6:312-18.http://dx.doi.org/10.1016/j.stam.2005.02.018

11. Raveh A, Zukerman I, Shneck R, Avni R, Fried I Thermal stability of nanostructured superhard coatings: a review. Surf. Coat. Technol. 2007; 201:6136-42.http://dx.doi.org/10.1016/j.surfcoat.2006.08.131

12. Bhattacharya D, Rajinder G Nanotechnology and potential of microorganisms. Critical Reviews in Biotechnology, 2005; 25:199. 204.http://dx.doi.org/10.1080/07388550500361994

13. Osaka T, Matsunaga T, Nakanishi T, Arakaki A, Niwa D, Iida H Synthesis of magnetic nanoparticles and their application to bioassays. Analytical and Bioanalytical Chemistry, 2006; 384: 593600.http://dx.doi.org/10.1007/s00216-005-0255-7

14. Singh M, Singh S, Prasad S, Gambhir IS Nanotechnology in medicine and antibacterial effect of silver nanoparticles.Dig. J. Nanomater. Bios.2008; 3: 115-122.

15. Kowshik M, Ashtaputre S, Kharrazi S, Vogel W, Urban J, Kulkarni SK, Paknikar KM Extracellular synthesis of silver nanoparticles by a silver-tolerant yeast strain MKY3. Nanotechnology, 2003; 14: 95100.http://dx.doi.org/10.1088/0957-4484/14/1/321

16. Bansal V, Rautaray D, Bharde A, Ahire K, Sanyal A, Ahmad A, Sastry M Fungus mediated biosynthesis of silica and titania particles. J. Mat. Chem. 2005; 15: 2583-89.http://dx.doi.org/10.1039/ b503008k

17. Kumar SA, Abyaneh MK, Gosavi SW, Kulkarni SK, Pasricha R, Ahmad A, Khan MI Nitrate reductase-mediated synthesis of silver nanoparticles from $\mathrm{AgNO}_{3}$. Biotechnology Letters, 2007; 29: 439445.http://dx.doi.org/10.1007/s10529-006-9256-7

18. Dickson DPE Nanostructured magnetism in living systems. $J$ of Magnetism and Magnetic Materials,1999; 203: 46-49.http://dx.doi. org/10.1016/S0304-8853(99)00178-X

19. Senapati S, Mandal D, Ahmad A, Khan MI, Sastry M, Kumar R Fungus mediated synthesis of silver nanoparticles: a novel biological approach. Indian Journal of Physics A, 2004; 78: 101-105.

20. Gericke M Pinches A Biological synthesis of metal nanoparticles. Hydrometallurgy, 2006; 83: 132-140. 
http://dx.doi.org/10.1016/j.hydromet.2006.03.019

21. Shankar SS, Rai A, Ahmad A, Sastry MJ Rapid synthesis of Au, Ag, and bimetallic Au core-Ag shell nanoparticles using Neem (Azadirachta indica) leaf broth. Journal of Colloid and Interface Science, 2004; 275:496-502.http://dx.doi.org/10.1016/ j.jcis.2004.03.003

22. Mandal D, Bolander ME, Mukhopadhyay D, Sarkar G, Mukherjee P The use of microorganisms for the formation of metal nanoparticles and their application. Applied Microbiology and Biotechnology, 2006; 69: 485-492.http://dx.doi.org/10.1007/s00253-005-0179-3

23.Mohanpuria P, Nisha K, Rana NK, Yadav SK Biosynthesis of nanoparticles: technological concepts and future applications. $J$. Nanopart. Res. 2008; 10:507-517.http://dx.doi.org/10.1007/s11051007-9275-X

24. Joerger R, Klaus T, Granqvist CG Biologically produced Ag-C composite materials for optically functional thin film coatings. Adv. Mat. 2000; 12:407-409.http://dx.doi.org/10.1002/(SICI)15214095(200003)12:6<407::AID-ADMA407>3.0.CO;2-O

25. Nair B and Pradeep T. Coalescence of nanoclusters and formation of submicron crystallites assisted by Lactobacillus strains. Crystal Growth and Design 2002; 2: 293- 298.http://dx.doi.org/10.1021/ $\operatorname{cg} 0255164$

26. Shahverdi AR, Minaeian S, Shahverdi HR, Jamalifar H, Nohi AA. Rapid synthesis of silver nanoparticles using culture supernatants of Enterobacteriaceae: A novel biological approach. Process Biochem. 2007; 42: 919- 923.http://dx.doi.org/10.1016/ j.procbio.2007.02.005

27. Mokhtari N, Daneshpajouh S, Seyedbagheri S, Atashdehghan R, Abdi K, Sarkar S, Minaian S, Shahverdi HR, Shahverdi AR. Biological synthesis of very small silver nanoparticles by culture supernatant of Klebsiella pneumonia: The effects of visible-light irradiation and the liquid mixing process. Mat. Res. Bull. 2009; 44: 1415-1421.http://dx.doi.org/10.1016/j.materresbull.2008.11.021

28. Kalishwaralal K, Deepak V, Ramkumarpandian S, Nellaiah H, Sangiliyandi G. Extracellular biosynthesis of silver nanoparticles by the culture supernatant of Bacillus licheniformis. Materials Letters 2008; 62: 4411-4413.http://dx.doi.org/10.1016/ j.matlet.2008.06.051

29. Varshney R, Bhadauria S, Gaur MS, Pasricha R. Characterization of copper nanoparticles synthesized by a novel microbiological method, JOM (Journal of Metals) 2010; 62(12): 100-102.http://dx.doi. org/10.1007/s11837-010-0171-y

30.Varshney R, Bhadauria S, Gaur MS, Pasricha R. Copper nanoparticles synthesis from electroplating industry effluent. Nano Biomed. Eng. 2011; 3(2): 115-119. http://dx.doi.org/10.5101/nbe. v3i2.p115-119

31. Prakash A, Sharma S, Ahmad N, Ghosh A, Sinha P. Synthesis of AgNPs by Bacillus Cereus bacteria and their antimicrobial potential. Journal of Biomaterials and Nanobiotechnology 2011; 2: 156-162. http://dx.doi.org/10.4236/jbnb.2011.22020

32. Dameron CT, Reeser RN, Mehra RK, Kortan AR, Carroll PJ, Steigerwaldm ML, Brus LE, Winge DR. Biosynthesis of cadmium sulphide quantum semiconductor crystallites. Nature 1989; 338 596-597.http://dx.doi.org/10.1038/338596a0

33. Govindaraju K, Kiruthiga V, Ganesh Kumar V, Singaravelu G. Extracellular synthesis of silver nanoparticles by a marine alga, Sargassum wightii Grevilli and their antibacterial effects. Journal of Nanoscience and Nanotechnology 2009; 9(9): 5497-5501. http://dx.doi.org/10.1166/jnn.2009.1199

34. Mohseniazar MM, Barin M, Zarredar H, Alizadeh S and Shanehbandi D. Potential of Microalgae and Lactobacilli in Biosynthesis of Silver Nanoparticles, BioImpacts 2011; 1(3): 149152

35. Sastry M, Ahmad A, Khan MI, Kumar R. Biosynthesis of metal nanoparticles using fungi and actinomycetes. Current Science 2003 85: $162-170$.

36. Ahmad A, Mukherjee P, Mandal D, Senapati S, Khan MI, Kumar R, Sastry M. Extracellular biosynthesis of silver nanoparticles using the fungus Fusarium oxysporum composite metal particles, and the atom to metal. Colloids and Surfaces B: Biointerfaces 2003; 28 : 313-318.http://dx.doi.org/10.1016/S0927-7765(02)00174-1

37. Bhainsa KC and D'Souza SF. Extracellular biosynthesis of silver nanoparticles using the fungus Aspergillus fumigatus.
Colloids and Surfaces B: Biointerfaces 2006; 47: 160-164. http://dx.doi.org/10.1016/j.colsurfb.2005.11.026

38. Vigneshwaran N, Kathe AA, Varadarajan PV, Nachane RP, Balasubramanya RH. Biomimetics of Ag nanoparticles by white rot fungus, Phaenerochaete chrysosporium. Colloids and Surfaces B. Biointerfaces 2006; 53: 55-59.http://dx.doi.org/10.1016/ j.colsurfb.2006.07.014

39. Gade AK, Bonde PP, Ingle AP, Marcato P, Duran N, Rai MK. Exploitation of Aspergillus niger for synthesis of silver nanoparticles Journal of Biobased Materials and Bioenergy 2008; 2: 1-5. http://dx.doi.org/10.1166/jbmb.2008.401

40. Vigneshwaran N, Ashtaputre NM, Varadarajan PV, Nachane RP, Paralikar KM, Balasubramanya RH. Biological synthesis of silver nanoparticles using the fungus Aspergillus flavus. Materials Letters 2007; 61: 1413-1418.http://dx.doi.org/10.1016/j.matlet.2006.07.042

41. Ingle A, Gade A, Pierrat S, Sonnichsen C, Rai M. Mycosynthesis of silver nanoparticles using the fungus Fusarium acuminatum and its activity against some human pathogenic bacteria. Current Nanoscience 2008; 4: 141-144.http://dx.doi.org/10.2174/157341308 784340804

42. Basavaraja SS, Balaji SD, Lagashetty AK, Rajasab AH, Venkataraman A. Extracellular biosynthesis of silver nanoparticles using the fungus Fusarium semitectum. Materials Research Bulletin 2008; 43: 1164-1170.http://dx.doi.org/10.1016/j.materresbull. 2007.06.020

43. Ingle A, Rai M, Gade A, Bawaskar M. Fusarium solani: a novel biological agent for the extracellular synthesis of silver nanoparticles. Journal of Nanoparticle Research 2009; 11(8): 207985.http://dx.doi.org/10.1007/s11051-008-9573-y

44. Sanghi R. and Verma P. Biomimetic synthesis and characterization of protein capped silver nanoparticles. Bioresource Technology 2009; 100: 501-504.http://dx.doi.org/10.1016/j.biortech.2008.05.048

45. Sadowski, Z, Maliszewska, IH, Grochowalska, B, Polowczyk, I, Kozlecki, T. Synthesis of silver nanoparticles using microorganisms. Materials Science-Poland 2008; 26: 419-425.

46. Kathiresan K, Manivannan S, Nabeel MA, Dhivya B. Studies on silver nanoparticles synthesized by a marine fungus, Penicillium fellutanum isolated from coastal mangrove sediment. Coll. and Surf B: Biointer. 2009; 71: 133-137.http://dx.doi.org/10.1016/ j.colsurfb.2009.01.016

47. Birla SS, Tiwari VV, Gade AK, Ingle AP, Yadav AP, Rai MK Fabrication of silver nanoparticles by Phoma glomerata and its combined effect against Escherichia coli, Pseudomonas aeruginosa and Staphylococcus aureus. Lett. in App. Microbiol. 2009; 48: 173179

48. Duran N, Marcato PD, Alves OL, Souza GI, Esposito E. Mechanistic aspects of biosynthesis of silver nanoparticles by several Fusarium oxysporum strains. Journal of Nanobiotechnology 2005; 3: 8-14. http://dx.doi.org/10.1186/1477-3155-3-8

49. Nithya R, Raghunathan R. Synthesis of silver nanoparticles using Pleurotus sajor caju and its antimicrobial study. Dig. J. Nanomater. Bios. 2009; 4(4): 623-629.

50. Varshney R, Mishra AN, Bhadauria S, Gaur MS. A novel microbial route to synthesize silver nanoparticles using fungus Hormoconis resinae. Dig. J. Nanomater. Bios. 2009; 4(2): 349-355.

51. Li G, He D, Qian Y, Guan B, Gao S, Cui Y, Yokoyama K, Wang L. Fungus-mediated green synthesis of silver nanoparticles using Aspergillus terreus. Int. J. Mol. Sci. 2011; 13: 466-476; http://dx.doi. org/10.3390/ijms13010466

52. Huang J, Li Q, Sun D, Lu Y, Su Y, Yang X, Wang H, Wang Y, Shao W, He N, Hong J, Chen C. Biosynthesis of silver and gold nanoparticles by novel sundried Cinnamomum camphora leaf. Nanotechnology 2007; 18: 105104-115.http://dx.doi.org/10.1088/09574484/18/10/105104

53. Shankar SS, Rai A, Ahmad A, Sastry M. Biosynthesis of silver and gold nanoparticles from extracts of different parts of the Geranium plant. Applications in Nanotechnology 2004; 1: 69-77.

54. Shankar SS, Rai A, Ahmad A, Sastry M. Rapid synthesis of Au, Ag, and bimetallic Au core-Ag shell nanoparticles using Neem (Azadirachta indica) leaf broth. Journal of Colloid and Interface Science 2004; 275(2): 496-502.http://dx.doi.org/10.1016/ j.jcis.2004.03.003

55. Ankamwar B, Damle C, Ahmad A, Sastry M. Biosynthesis of gold 
and silver nanoparticles using Emblica officinalis fruit extract, their phase transfer and transmetallation in an organic solution. $J$ of Nanosci. and Nanotechnol. 2005; 5: 1665-1671.http://dx.doi. org/10.1166/jnn.2005.184

56. Chandran SP, Chaudhary M, Pasricha R, Ahmad A, Sastry M. Nanotriangles and silver nanoparticles using Aloe vera plant extract. Biotechnology Programme 2006; 22: 577-583.http://dx.doi. org/10.1021/bp0501423

57. Gardea-Torresdey JL, Gomez E, Peralta-Videa JR, Parsons JG, Troiani H, Jose-Yacaman M. Alfalfa sprouts: a natural source for the synthesis of silver nanoparticles. Langmuir 2003; 19: 1357-1361. http://dx.doi.org/10.1021/la020835i

58. Shankar SS, Ahmad A, Sastry M. Geranium leaf assisted biosynthesis of silver nanoparticles. Biotechnology Programme 2003; 19: 1627-1631.http://dx.doi.org/10.1021/bp034070w

59. Leela A and Vivekanandan M. Tapping the unexploited plant resources for the synthesis of silver nanoparticles. African $J$ of Biotechnology 2008; 7: 3162-65.

60. Xu H and Kall M. Morphology effects on the optical properties of silver nanoparticles. Journal of Nanoscience and Nanotechnology 2002; 4: 254-259.

61. Mude N, Ingle A, Gade A, Rai M. Synthesis of silver nanoparticles using callus extract of Carica papaya- A First Report. J of Plant Biochem and Biotechnol. 2009; 18: 83-86.

62. Bar H, Bhui DK, Sahoo GP, Sarkar P, De SP, Misra A. Green synthesis of silver nanoparticles using latex of Jatropha curcas. Colloids and Surfaces A: Physicochemical and Engineering Aspects 2009; 339: 134-139.http://dx.doi.org/10.1016/j.colsurfa.2009.02.008

63. Jha AK, Prasad K, Kumar V, Prasad K. Biosynthesis of silver nanoparticles using Eclipta leaf. Biotechnol. Prog. 2009; 25(5): 1476-1479.http://dx.doi.org/10.1002/btpr.233

64. Vivekanandan S, Misra M, Mohanty A. Biological synthesis of silver nanoparticles using Glycine $\max$ (soybean) leaf extract: an investigation on different varieties. J of nanoscience \& Nanotechnol. 2009; 9(12): 6828-6833.

65. Sathyavathi R, Balamurali KM, Venugopal S, Saritha R, Narayana RD. Biosynthesis of Ag nanoparticles using Coriandrum sativum leaf extract and their application in non-linear optics. Adv.Sci.Lett. 2010; 3(2): 138-143.http://dx.doi.org/10.1166/asl.2010.1099

66. Kumar V, Yadav SC, Yadav SK. Syzygium cumini leaf and seed extract mediated biosynthesis of silver nanoparticles and their characterization. $J$ of chem. Technol. Biotechnol. 2010; 85: 13011309.http://dx.doi.org/10.1002/jctb.2427
67. Jha AK, Prasad K. Green synthesis of silver nanoparticles using Cycas leaf. Int. J. of Green Nanotechnology: Physics and Chemistry 2010; 1: 110-117.http://dx.doi.org/10.1080/19430871003684572

68. Khandelwal N, Singh A, Jain D, Upadhay MK, Verma HN. Green synthesis of silver nanoparticles using Argimone mexicana leaf extract and valuation of their antimicrobial activities. Dig. J. Nanomater. Bios. 2010; 5(2): 483-489.

69. Saxena A, Tripathi RM, Singh RP. Biological synthesis of silver nanoparticles by using onion (Allium cepa) extract and their antibacterial activity. Dig. J. Nanomater. Bios. 2010; 5(2): 427-432.

70. Varshney R, Bhadauria S, Gaur MS. Biogenic synthesis of silver nanocubes and nanorods using sundried Stevia rebaudiana leaves. Adv. Mat. Lett. 2010; 1(3): 232-237.http://dx.doi.org/10.5185/ amlett.2010.9155

71.Govindaraju K, Tamilselvan S, Kiruthiga V, Singaravelu G. Biogenic silver nanoparticles by Solanum torvum and their promising antimicrobial activity. Journal of Biopesticides 2010; 3(1): 394-399.

72. Guajardo-Pacheco Ma J, Morales-Sanchez JE, Gonzalez-Hernandez J, Ruiz F. Synthesis of copper nanoparticles using soybeans as a chelant agent. Materials letters 2010; 64(12): 1361-64.http://dx.doi. org/10.1016/j.matlet.2010.03.029

73. Singh C, Sharma V, Naik PK, Khandelwal V, Singh H. Green biogenic approach for synthesis of gold and silver nanoparticles using Zingiber officinale. Dig. J. Nanomater. Bios. 2011; 6(2): 535 542 .

74. Lee HJ, Lee G, Jang NR, Yun JM, Song JY, Kim BS. Biological synthesis of copper nanoparticles using plant extract. Nanotech. 2011; 1: 371-374.

75. Parashar V, Parashar R, Sharma B, Pandey AC. Parthenium leaf extract mediated synthesis of silver nanoparticles: a novel approach towards weed utilization. Dig. J. Nanomater. Bios. 2009; 4: 45-50.

76. Roy N and Barik A. Green Synthesis of Silver Nanoparticles from the Unexploited Weed Resources. Int. J. of Nanotechnol. App. 2010; 4(2): 95-101.

Copyright:(c) 2012 Ratnika Varshney, et al. This is an open-access article distributed under the terms of the Creative Commons Attribution License, which permits unrestricted use, distribution, and reproduction in any medium, provided the original author and source are credited. 